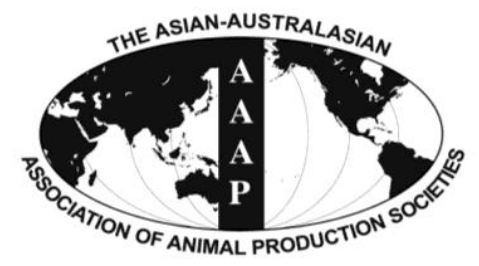

Asian Australas. J. Anim. Sci.

Vol. 26, No. 10 : 1504-1510 October 2013

http://dx.doi.org/10.5713/ajas.2013.13097

www.ajas.info

pISSN 1011-2367 elSSN 1976-5517

\title{
Effect of Hybridization on Carcass Traits and Meat Quality of Erlang Mountainous Chickens
}

\author{
H. D. Yin, E. R. Gilbert ${ }^{1}$, S. Y. Chen ${ }^{2}$, Y. Wang ${ }^{2}$, Z. C. Zhang, X. L. Zhao, Yao Zhang, and Q. Zhu* \\ College of Animal Science and Technology, Sichuan Agricultural University, Ya'an, Sichuan, 625014, China
}

\begin{abstract}
Native chickens hold a significant share of the market in China. In response to the huge demand from the market, the productivity of Chinese native chickens needs to be improved. Cross breeding is an effective method to increase productivity, although it might affect meat quality. In this study, two pure lines (SD02 and SD03) of Erlang mountainous chickens were hybridized with a yellow feather and faster growing line (SD01). The effect of hybridization on carcass and meat quality (physiochemical and textural traits) was measured in the $F_{1}$ population at $\mathrm{d} 91$ of age. The hybrids exhibited higher body weight and dressed weight, and amount of semieviscerated, eviscerated, breast muscle and abdominal fat $(p<0.05)$. Abdominal fat yield also increased $(p<0.05)$ compared to the offspring of the two pure-lines. Meanwhile, there was no significant difference in meat quality traits except for the myofiber diameter and density and the shear force of the breast muscle. Overall, the offspring of cross-lines were similar to pure lines in meat color, $\mathrm{pH}$ value, inosinic acid, crude protein, crude fat, dry matter, moisture content and amino acid composition in the breast muscle. These results suggest that productivity can be improved via cross-breeding while maintaining meat quality of the Erlang mountainous chicken. (Key Words: Hybridization, Carcass Traits, Meat Quality, Erlang Mountainous Chicken)
\end{abstract}

\section{INTRODUCTION}

White meat, such as poultry, fish and seafood, is considered healthier than red meat (beef and mutton) because of comparably low fat and cholesterol content. Consumption of chicken, with its low price and rare religious restrictions, shows a rising demand (Jaturasitha et al., 2008). In China, indigenous Chinese chickens, which are raised to market weight over $80 \mathrm{~d}$, are more popular despite their higher retail price compared to standard broilers, because they have more flavorful meat and important traits for Chinese cooking (Chen, 2010). Therefore, the Chinese native chicken market is rapidly growing at a rate of 5 to $10 \%$ per year (Tang et al., 2009). Chinese native chickens are superior to fast-growing broiler lines (e.g. Cobb and Ross) in nutrient composition, but the growth rate and feed efficiency are poor (Qi et al., 2006; Wang et al., 2009a).

\footnotetext{
* Corresponding Author: Qing Zhu. Tel: +86-835-2882006, Fax: +86-835-2886080, E-mail: zhuqingsicau@163.com

${ }^{1}$ Department of Animal and Poultry Science, Virginia Polytechnic Institute and State University, Blacksburg, VA, 24061, USA.

${ }^{2}$ Institute of Animal Genetics and Breeding, Sichuan Agricultural University, Chengdu Campus, Chengdu 611130, China.

Submitted Feb. 10, 2013; Accepted Jun. 4, 2013; Revised Jun. 14, 2013
}

In response to the huge market demand, the productivity of Chinese native chickens should be improved. Production performance largely depends on genetics, but progress is limited by purebred breeding. Fortunately, cross-breeding can effectively solve this problem. Crossbreeding of the indigenous chickens with fast-growing commercial birds will make full use of natural selection for resistance and artificial selection for productivity in exotic chickens (Adebambo et al., 2010). The optimal crossbred animal would have higher growth rate, feed conversion efficiency, reproductive and carcass performance without sacrificing adaptation to the local environment (Adebambo, 2011; Odeh et al., 2003). Consequently, the body composition and growth rate of Chinese native chickens have largely improved, although resistance to pathogens and environmental stressors has decreased (Chen et al., 2005; Jin et al., 2005; Li et al., 2007; Wang et al., 2008). These characteristics are very important in free-range production systems that require outdoor exposure. China's General Administration of Quality Supervision, Inspection and Quarantine prohibits the use of allopathic drugs, thus pathogen exposure is a major concern in a free-range system. Meat quality has also been altered by this type of selection. Meat color, ultimate $\mathrm{pH}$ and tenderness of muscle and other meat quality indices appeared to decline after 
hybridization (Le Bihan-Duval et al., 1999; Remignon et al., 1996).

Erlang mountainous chickens are selected by Sichuan Agricultural University and Ya'an Longsheng Animal Husbandry Co., Ltd, and originated from a local chicken breed in Ya'an, Sichuan province, including two lines, SD02 and SD03, which are widely adaptable, and have delicious and nutritious meat but show lower growth rate and productivity (Lan et al., 2010). In order to improve their productive performance, line SD01 which is a yellow feather, faster growing chicken (more than $3.5 \mathrm{~kg}$ at $80 \mathrm{~d}$ ) was crossbred to SD02 and SD03. The objective of this study was to determine the effect of hybridization on carcass yield and meat quality among different lines (SD02, SD03, SD01 $\times$ SD02, and SD01 $\times$ SD03). The results could reveal important traits for further breeding of Erlang mountainous chickens.

\section{MATERIAL AND METHODS}

\section{Experimental design and bird management}

The experiment was a complete randomized design (Stell and Torrie, 1980). Line SD01 was employed as the male line to cross with SD02 and SD03. A total of $800 \mathrm{~F}_{1}$ chickens were chosen, including two pure-lines (SD02 and SD03) and two crossbred-lines of Erlang mountainous chickens (SD01×SD02 and SD01×SD03.) There were 200 chickens in each line with equal numbers of males and females. Chickens were raised from $1 \mathrm{~d}$ to $91 \mathrm{~d}$ at the Sichuan Agricultural University Poultry Breeding Farmland. The stocking density was $8-10$ birds per $\mathrm{m}^{2}$. All birds had ad libitum access to water and feeding, and nutrients levels as recommended by the NRC (1998).

\section{Traits measured}

At the market age of $91 \mathrm{~d}, 30$ chickens (15 males and 15 females) were randomly sampled from each line. The chickens were fasted for $12 \mathrm{~h}$, weighed and then killed by cervical dislocation and decapitation. After slaughter, dressed weight (DW), semi-eviscerated weight (SEW), eviscerated weight (EW), breast muscle weight (BMW), leg muscle weight (LMW), and abdominal fat weight (AFW) were measured. The $\mathrm{CW}$ was measured on the carcass after removal of the feathers. SEW was measured on the carcass after removal of the trachea, esophagus, gastrointestinal tract, spleen, pancreas and gonads. The EW was measured after further removal of the head, claws, heart, liver, gizzard, glandular stomach and abdominal fat. The percentage of $\mathrm{CW}, \mathrm{EW}$ and SEW relative to $\mathrm{BW}$ were calculated as carcass yield (CY), eviscerated yield (EY), and semieviscerated yield (SEY), respectively. The ratios of BMW and LMW to EW were calculated as breast muscle yield
(BMY) and leg muscle yield (LMY), respectively. Abdominal fat yield (AFY) was calculated as the percentage of AFW to both EW and AFW. All measures followed the requirements of the Director Proposals of Poultry Science (Zhu, 2004).

The diameter and density of the breast muscle fibers were measured on the left pectoral major muscle $(3 \mathrm{~cm} \times 2$ $\mathrm{cm})$. The muscle slices were cut following the direction of muscle fibers in the middle of the muscle. Tissues were fixed in neutral-buffered formalin, embedded in paraffin, cut into $6 \mu \mathrm{m}$ slices, and stained with hematoxylin-eosin (H-E). Fiber diameter measurements were performed on each stained section under light-microscopy $(400 \times)$ and the number of breast muscle cells per square millimeter was computed (Chen et al., 2002b).

The shear force value was evaluated according to the method of Chen (2007) with some modifications (Chen et al., 2007). Muscle samples from right pectoral major muscle were kept at $4^{\circ} \mathrm{C}$ for $24 \mathrm{~h}$. After packaging and sealing in a boilable bag, samples were cooked to an internal temperature of $70^{\circ} \mathrm{C}$ in a water bath. Ten minutes was required to reach the end-point temperature. Upon reaching the desired temperature, muscle samples were removed and cooled to room temperature. A $1.27 \mathrm{~cm}$ diameter core was removed from each sample parallel to the myofiber orientation for shearing perpendicularly to the longitudinal orientation of the myofibers using a Digital Meat Tenderness Meter (Model C-LM3). Test speed was 5 $\mathrm{mm} / \mathrm{s}$ and maximum force needed to cut the strips was expressed in newtons. For each cooked breast muscle, the strip was sheared in two locations, and the average was used for data analysis.

Muscle $\mathrm{pH}$ at $45 \mathrm{~min}\left(\mathrm{pH}_{45 \min }\right)$ and $24 \mathrm{~h}\left(\mathrm{pH}_{24 \mathrm{~h}}\right)$ postmortem (storage temperature of 0 to $4^{\circ} \mathrm{C}$ ) was measured directly on the three random parts of pectoral major muscle using a pH-Star meter (Orion Co., Ltd., USA). Three measurements were recorded and averaged for each sample. Meat color was determined on the medial surface of the breast muscle (in an area free from color defects, bruising and hemorrhages) with a Minolta CR310 (Minolta Camera Co., Ltd., Japan) at 1 to $2 \mathrm{~h}$ postmortem. The lightness, redness and yellowness $\left(\mathrm{L}^{*}, \mathrm{a}^{*}\right.$ and $\mathrm{b}^{*}$ values, respectively) were recorded. Each test was performed three times and triplicate measurements averaged.

Meanwhile, a muscle sample was collected from the left breast muscle, carefully avoiding inter-muscular fat depots surrounding the muscle. Moisture content (MC) was determined by oven drying, and crude fat (CF) was measured using Soxhlet petroleum-ether extraction (Luque de Castro and Priego-Capote, 2010). The crude protein (CP) was determined using the Kjeldahl method (Hawk, 1947). Inosinic acid (IMP) content was determined by high 
Performance Liquid Chromatography (Agilent 1100 HPLC; Agilent, Co., Ltd., USA). The composition of amino acids was determined on a high-speed amino acid analyzer (L8800; HITACHI, Co., Ltd., Japan).

\section{Statistical analyses}

Statistical analysis was carried out using SPSS 17.0. Data for all traits were subjected to two-way ANOVA and the statistical model included the main effects of line and sex and interaction between them. Differences among lines were separated using Tukey's test and Difference between sex was using Paired-samples $\mathrm{T}$ test. Differences were considered significant at $\mathrm{p}<0.05$.

\section{RESULTS AND DISCUSSION}

The improvement in growth rate from cross-breeding might lead to decrease in meat quality, which is a critical issue in animal production (Zhang et al., 2008). The most effective solution is biotechnology (Yin et al., 2011). Unfortunately, this technology is still in its infancy. Breeding specialized strains and screening outstanding hybrid matching lines are still the most common and reliable methods for improving growth rate without sacrificing meat quality.

\section{Carcass characteristics}

The carcass traits of chickens were analyzed separately for line, sex and interaction between line and sex and a summary of data is shown in Table 1 . There was a main effect of line on the carcass traits. Although the carcass traits were significantly affected by line and sex, interaction of line $\times$ sex was not significant for any trait. As expected, hybridization affected all traits. The $\mathrm{F}_{1}$ generations from the two hybrid lines exhibited greater BW, DW, EW, SEW, BMW, AFW, and AFY ( $<<0.05)$, compared with the two pure-lines. In general, these results show that cross offspring had more edible parts and higher economic value. The CY and EY are the main indices to evaluate the meat productivity in chickens. For Chinese native chickens, it is generally accepted that a carcass yield greater than $80 \%$ and eviscerated yield greater than $60 \%$ is regarded as satisfactory in terms of meat performance (Xie et al., 2008). There was no significant difference among lines in CY and EY, but the CY of the four genotypes ranged from $87.87 \%$ to $88.74 \%$ and the EY in all lines was greater than $64 \%$, which suggests that all four lines have superior meat production capacities. Moreover, sex also affected carcass traits, with males having greater BW, DW, SEW, EW, BMW, LMW, CY, LMY, and BMY as compared to females ( $\mathrm{p}<$ 0.05). In contrast, the females showed greater AFW and AFY than males $(p<0.05)$, which indicates that females deposited more abdominal fat, consistent with the report that females had a higher percentage abdominal fat than males in a Chinese local breed (Zhao et all, 2012). This is an adaptation where females are evolutionarily hard-wired to prepare and maintain egg production (Zhao et al., 2012).

\section{Meat characteristics}

The physical characteristics of muscle are intuitively the most important indicators of meat quality. As shown in Table 2, neither line nor sex affected meat color and $\mathrm{pH}$ values $\left(\mathrm{pH}_{45}\right.$ min, $\mathrm{pH}_{24 \mathrm{~h}}$ and $\left.\mathrm{pH}_{\text {reduction }}\right)$. These results show that meat color and $\mathrm{pH}$ value were similar in all lines and

Table 1. Effects of line, sex, and their interaction on carcass traits

\begin{tabular}{|c|c|c|c|c|c|c|c|c|c|c|c|}
\hline \multirow{2}{*}{ Item $^{1}$} & \multicolumn{6}{|c|}{ Line } & \multicolumn{4}{|c|}{ Sex } & \multirow{2}{*}{$\frac{\text { Interaction }^{2}}{\mathrm{p}}$} \\
\hline & SD02 & SD03 & SD01×SD02 & SD01×SD03 & SEM & $\mathrm{p}$ & Male & Female & SEM & $\mathrm{p}$ & \\
\hline $\mathrm{BW}(\mathrm{g})$ & $2,743^{\mathrm{b}}$ & $2,679^{\mathrm{b}}$ & $2,935^{\mathrm{a}}$ & $3,001^{\mathrm{a}}$ & 48.0 & $<0.001$ & $3,271^{\mathrm{a}}$ & $2,421^{\mathrm{b}}$ & 48.0 & $<0.001$ & 0.971 \\
\hline DW $(g)$ & $2,408^{\mathrm{b}}$ & $2,348^{\mathrm{b}}$ & $2,602^{\mathrm{a}}$ & $2,681^{\mathrm{a}}$ & 40.2 & $<0.001$ & $2,861^{\mathrm{a}}$ & $2,155^{\mathrm{b}}$ & 40.2 & $<0.001$ & 0.925 \\
\hline SEW (g) & $2,245^{\mathrm{b}}$ & $2,213^{\mathrm{b}}$ & $2,410^{\mathrm{a}}$ & $2,481^{\mathrm{a}}$ & 38.8 & $<0.001$ & $2,680^{\mathrm{a}}$ & $1,995^{\mathrm{b}}$ & 38.8 & $<0.001$ & 0.941 \\
\hline EW (g) & $1,763^{\mathrm{b}}$ & $1,754^{\mathrm{b}}$ & $1,897^{\mathrm{a}}$ & $1,944^{\mathrm{a}}$ & 33.7 & $<0.001$ & $2,121^{\mathrm{a}}$ & $1,566^{\mathrm{b}}$ & 31.5 & $<0.001$ & 0.862 \\
\hline BMW (g) & $304.3^{\mathrm{b}}$ & $314.9^{\mathrm{b}}$ & $374.2^{\mathrm{a}}$ & $382.2^{\mathrm{a}}$ & 5.61 & 0.011 & $354.8^{\mathrm{a}}$ & $284.1^{\mathrm{b}}$ & 5.61 & $<0.001$ & 0.871 \\
\hline LMW (g) & $400.6^{\mathrm{b}}$ & $400.2^{\mathrm{b}}$ & $429.4^{\mathrm{ab}}$ & $445.9^{\mathrm{a}}$ & 9.35 & 0.024 & $506.5^{\mathrm{a}}$ & $342.1^{\mathrm{b}}$ & 9.35 & $<0.001$ & 0.176 \\
\hline AFW (g) & $83.45^{\mathrm{b}}$ & $87.51^{\mathrm{b}}$ & $112.1^{\mathrm{a}}$ & $118.9^{\mathrm{a}}$ & 3.69 & 0.001 & $88.5^{\mathrm{b}}$ & $112.1^{\mathrm{a}}$ & 3.67 & $<0.001$ & 0.349 \\
\hline CY $(\%)$ & 87.9 & 88.6 & 88.5 & 88.7 & 2.85 & 0.669 & $89.0^{\mathrm{a}}$ & $87.6^{\mathrm{b}}$ & 0.29 & 0.018 & 0.136 \\
\hline $\operatorname{SEY}(\%)$ & 81.9 & 82.6 & 82.0 & 82.2 & 3.18 & 0.673 & 82.3 & 82.1 & 0.31 & 0.759 & 0.115 \\
\hline EY (\%) & 64.5 & 65.4 & 64.7 & 64.8 & 2.63 & 0.205 & 64.9 & 64.6 & 0.27 & 0.509 & 0.403 \\
\hline BMY (\%) & 17.8 & 18.1 & 18.6 & 18.7 & 1.65 & 0.184 & $18.2^{\mathrm{a}}$ & $16.7^{\mathrm{b}}$ & 0.18 & $<0.001$ & 0.601 \\
\hline $\operatorname{LMY}(\%)$ & 22.7 & 22.9 & 22.8 & 22.9 & 2.01 & 0.195 & $23.8^{\mathrm{a}}$ & $22.0^{\mathrm{b}}$ & 0.21 & $<0.001$ & 0.112 \\
\hline $\operatorname{AFY}(\%)$ & $4.68^{\mathrm{b}}$ & $4.73^{\mathrm{b}}$ & $5.87^{\mathrm{a}}$ & $5.90^{\mathrm{a}}$ & 0.37 & 0.004 & $3.99^{\mathrm{b}}$ & $6.56^{\mathrm{a}}$ & 0.12 & $<0.001$ & 0.221 \\
\hline
\end{tabular}

${ }^{1} \mathrm{BW}=$ Body weight, DW = Dressed weight, SEW = Semi-eviscerated weight, EW = Eviscerated weight, BMW = Breast muscle weight, LMW = Leg muscle weight, $\mathrm{AFW}=$ Abdominal fat weight, $\mathrm{CY}=$ Carcass yield, $\mathrm{EY}=$ Eviscerated yield, $\mathrm{SEY}=$ Semi-eviscerated yield, $\mathrm{BMY}=\mathrm{Breast}$ muscle yield, $\mathrm{LMY}=$ Leg muscle yield, and AFY = Abdominal fat yield .

${ }^{2}$ Interaction of line and sex.

${ }^{a, b}$ Mean within a row and effect line or sex) with no common superscripts are significantly different $(\mathrm{p}<0.05)$. 
Table 2. Effects of line, sex, and their interaction on physical characteristics of chicken breast muscles

\begin{tabular}{|c|c|c|c|c|c|c|c|c|c|c|c|}
\hline \multirow{2}{*}{ Item $^{1}$} & \multicolumn{6}{|c|}{ Line } & \multicolumn{4}{|c|}{ Sex } & \multirow{2}{*}{$\frac{\text { Interaction }^{3}}{\mathrm{p}}$} \\
\hline & SD02 & SD03 & SD01×SD02 & SD01×SD03 & SEM & $\mathrm{p}$ & Male & Female & SEM & $\mathrm{p}$ & \\
\hline \multicolumn{12}{|l|}{ Meat color } \\
\hline $\mathrm{L}^{*}$ & 50.2 & 52.0 & 54.2 & 52.2 & 0.67 & 0.421 & 52.0 & 52.3 & 0.32 & 0.202 & 0.157 \\
\hline$a^{*}$ & 4.11 & 3.84 & 3.55 & 3.545 & 0.11 & 0.713 & 3.81 & 3.72 & 0.05 & 0.553 & 0.151 \\
\hline $\mathrm{b}^{*}$ & 7.56 & 7.68 & 7.02 & 6.95 & 0.32 & 0.121 & 7.41 & 7.19 & 0.18 & 0.351 & 0.411 \\
\hline \multicolumn{12}{|l|}{$\mathrm{pH}$} \\
\hline $\mathrm{pH}_{45 \text { min }}$ & 6.13 & 6.12 & 6.31 & 6.33 & 0.28 & 0.121 & 6.23 & 6.20 & 0.17 & 0.386 & 0.432 \\
\hline $\mathrm{pH}_{24 \mathrm{~h}}$ & 5.77 & 5.78 & 5.93 & 5.94 & 0.13 & 0.171 & 5.82 & 5.78 & 0.06 & 0.259 & 0.307 \\
\hline $\mathrm{pH}_{\text {reduction }}$ & 0.46 & 0.44 & 0.39 & 0.38 & 0.02 & 0.303 & 0.41 & 0.42 & 0.00 & 0.257 & 0.261 \\
\hline $\begin{array}{r}\mathrm{MF}_{\mathrm{Dia}}^{1} \\
(\mu \mathrm{m})\end{array}$ & $20.2^{\mathrm{b}}$ & $20.1^{\mathrm{b}}$ & $21.4^{\mathrm{a}}$ & $21.4^{\mathrm{a}}$ & 0.38 & 0.031 & $21.5^{\mathrm{a}}$ & $20.0^{\mathrm{b}}$ & 0.29 & 0.017 & 0.163 \\
\hline $\begin{array}{l}\mathrm{MF}_{\text {Den }}^{2} \\
\text { (num/mm } / \mathrm{mm}^{2} \text { ) }\end{array}$ & $2,161^{\mathrm{a}}$ & $2,134^{\mathrm{a}}$ & $2,020^{\mathrm{b}}$ & $1,988^{\mathrm{b}}$ & 77.4 & 0.031 & $2,016^{\mathrm{b}}$ & $2,137^{\mathrm{a}}$ & 53.9 & 0.021 & 0.225 \\
\hline $\begin{array}{l}\text { Shear force } \\
\text { (N) }\end{array}$ & $2.42^{\mathrm{b}}$ & $2.46^{\mathrm{b}}$ & $2.63^{\mathrm{a}}$ & $2.64^{\mathrm{a}}$ & 0.09 & 0.018 & $2.68^{\mathrm{a}}$ & $2.39^{\mathrm{b}}$ & 0.04 & 0.001 & 0.195 \\
\hline
\end{tabular}

${ }^{1} \mathrm{MF}_{\mathrm{Dia}}=$ The diameter of muscle fiber. ${ }^{2} \mathrm{MF}_{\mathrm{Den}}=$ The density of muscle fiber. ${ }^{3}$ Interaction of line and sex.

${ }^{a, b}$ Mean within a row and effect (line or sex) with no common superscripts are significantly different $(\mathrm{p}<0.05)$.

between males and females. Color is immediately discerned by consumers when purchasing meat products (Fanatico et al., 2007b). The $\mathrm{L}^{*}$ value indicates the paleness of meat, with a high $\mathrm{L}^{*}$ associated with poor meat quality. (Holownia et al., 2003; Wattanachant et al., 2004). That there was similar meat color across all genotypes suggests that the visual perception of the meat was not affected after hybridization. The muscle $\mathrm{pH}$ decreases after slaughter, and a low pH can inhibit water holding capacity (WHC) and other muscular functions (Owens et al., 2000; Woelfel et al., 2002). However, higher $\mathrm{pH}$ also negatively affects meat quality, because it creates a more favorable environment for bacterial growth (Fanatico et al., 2007a). In this study, the range of $\mathrm{pH}_{24 \mathrm{~h}}$ values were from 5.672 to 5.941 in all four lines, all within the normal range (Xiao, 2007), suggesting that cross-breeding did not alter meat quality.

Tenderness, which can be defined as how easy the meat can be chewed or cut, is considered to be the most critical meat quality evaluation index by consumers (Wang et al., 2009b). Muscle fiber characteristics including muscle fiber density and diameter have been shown to affect meat tenderness, with thinner, denser muscle fibers associated with greater tenderness (Gwartney et al., 1992). Shear force, which measures the textural integrity of cooked products, is a direct measure of tenderness. In our trial, line SD0 $1 \times$ SD02 and SD02 $\times$ SD03 had larger myofiber diameters $(\mathrm{p}<0.05)$ and reduced fiber density $(\mathrm{p}<0.05)$, as compared to the other two pure lines. The mean shear force for breast muscle in the two hybrids was greater than in the pure-lines $(p<0.05)$. Moreover, meat from males was chewier than meat from females due to the larger myofiber diameters and greater shear forces. These data illustrate that meat is chewier in hybrids and males and will better serve Chinese consumers due to their unique eating habits, particularly in the Southwest of China.

As shown in Table 3, there were no significant differences in the chemical composition of breast muscle among lines, including the percentage of moisture and dry matter, crude fat, crude protein and IMP. Likewise, sex did not influence these traits. The percentage of moisture and dry matter are important indices for meat quality. In general, the dry matter content is positively correlated with total nutrient content. The moisture contents of the four genotypes were approximately $72 \%$, whereas Shaarani et al. (2006) reported moisture content in broiler meat being as high as $76 \%$ (Shaarani et al., 2006). A certain fat content in

Table 3. Effects of line, sex, and their interaction on chemical composition of chicken breast muscles

\begin{tabular}{|c|c|c|c|c|c|c|c|c|c|c|c|}
\hline \multirow{2}{*}{ Item $^{1}$} & \multicolumn{6}{|c|}{ Line } & \multicolumn{4}{|c|}{ Sex } & \multirow{2}{*}{$\frac{\text { Interaction }^{2}}{\mathrm{p}}$} \\
\hline & SD02 & SD03 & SD01×SD02 & SD01×SD03 & SEM & $\mathrm{p}$ & Male & Female & SEM & $\mathrm{p}$ & \\
\hline $\mathrm{CF}(\%)$ & 6.43 & 6.52 & 6.58 & 6.76 & 0.42 & 0.257 & 6.41 & 6.73 & 0.31 & 0.251 & 0.101 \\
\hline IMP (g/mg) & 1.81 & 1.62 & 1.72 & 1.68 & 0.07 & 0.458 & 1.63 & 1.78 & 0.05 & 0.581 & 0.314 \\
\hline $\mathrm{CP}(\%)$ & 84.2 & 83.3 & 83.9 & 83.5 & 0.42 & 0.549 & 83.6 & 83.9 & 0.31 & 0.349 & 0.562 \\
\hline $\mathrm{DM}(\%)$ & 27.8 & 28.5 & 27.6 & 28.0 & 0.38 & 0.207 & 27.8 & 28.1 & 0.23 & 0.189 & 0.155 \\
\hline Water $(\%)$ & 72.3 & 71.5 & 72.4 & 72.0 & 0.38 & 0.207 & 72.2 & 71.9 & 0.23 & 0.189 & 0.155 \\
\hline
\end{tabular}

${ }^{1} \mathrm{CF}=$ Crude fat, IMP = Inosinic acid, $\mathrm{CP}=$ Crude protein, $\mathrm{DM}=$ Dry mater. ${ }^{2}$ Interaction of line and sex.

${ }^{a, b}$ Mean within a row and effect (line or sex) with no common superscripts are significantly different $(\mathrm{p}<0.05)$. 
muscle is not only able to enhance sensory perception, but also flavor, tenderness and juiciness (Van Laack et al., 2001). The muscular fat content in all four lines was around $6.5 \%$, suggesting that $\mathrm{CF}$ can also help improve the meat flavor in hybrids. IMP is a flavor precursor and is derived from the decomposition of ATP in muscle cells, its degradation resulting in formation of ribose in the meat (Davidek and Khan, 1967). In the current study, IMP in each genotype was $1.813 \mathrm{mg} / \mathrm{g}, 1.618 \mathrm{mg} / \mathrm{g}, 1.719 \mathrm{mg} / \mathrm{g}$ and $1.677 \mathrm{mg} / \mathrm{g}$ in SD02, SD03, SD01 $\times \mathrm{SD} 02$, and SD01 $\times$ SD03 respectively. These data are consistent with other reports of IMP in different Chinese native breeds (Chen et al., 2002a; Song et al., 2002). Undoubtedly genotype is a vital factor that can affect the IMP content, but we must also take into consideration the influence of stress induced during slaughtering, scalding temperature, postmortem storage condition etc.

The method used here allowed the accurate measurement of 16 amino acids. Amino acids are primary precursors of meat odor, and the protein composition of meat influences the flavors (Zhao et al., 2011). As shown in Table 4, the total content of the 16 amino acids in breast muscle did not differ ( $p>0.05$ ) among the four genotypes $(208.82 \mathrm{~g} / \mathrm{kg}, 208.18 \mathrm{~g} / \mathrm{kg}, 206.64 \mathrm{~g} / \mathrm{kg}$ and $207.12 \mathrm{~g} / \mathrm{kg}$ in SD02, SD03, SD01×SD02, and SD01×SD03, respectively). Similarly, no significant difference was found in contents of individual amino acids, essential amino acids (EAA) and flavor-related amino acids (FRAA). This demonstrates that amino acid composition is not associated with differences in nutrition and flavor of breast muscle in different offspring after crossing.

\section{CONCLUSION}

At the market age of $91 \mathrm{~d}$, hybridization was associated with beneficial effects on carcass traits. Most of the carcass indices in the cross-breeding descendants were greater than those in pure line's progenies. Moreover, outside shear force and muscle fiber density and diameter, meat quality traits were similar in all lines. Although the traits related to tenderness were affected by hybridization, they conform to the special dietary customs in southwestern China. These results suggested that the productivity of Erlang mountainous chickens can be improved by crossbreeding.

\section{ACKNOWLEDGEMENTS}

The authors thank Jiangyuan $\mathrm{Li}$ for farming the experimental chickens and thank Prof. Eric A Wong for revising the manuscript. This work was supported by China Agriculture Research System (CARS-41), The Twelfth Five Year Plan for breeding program in Sichuan (2011NZ00997 ), and the Programs from Sichuan Province (11TD007 and 2011JTD0032).

Table 4. Effects of line, sex, and their interaction on amino acid content in chicken breast muscles

\begin{tabular}{|c|c|c|c|c|c|c|c|c|c|c|c|}
\hline \multirow{2}{*}{$\begin{array}{l}\text { Item }^{1} \\
(\mathrm{mg} / \mathrm{g})\end{array}$} & \multicolumn{6}{|c|}{ Line } & \multicolumn{4}{|c|}{ Sex } & \multirow{2}{*}{$\frac{\text { Interaction }^{3}}{\mathrm{p}}$} \\
\hline & SD02 & SD03 & SD01×SD02 & SD01×SD03 & SEM & $\mathrm{p}$ & Male & Female & SEM & $\mathrm{p}$ & \\
\hline Aspartic acid & 22.8 & 22.2 & 22.7 & 22.6 & 0.39 & 0.072 & 22.5 & 22.6 & 0.25 & 0.567 & 0.715 \\
\hline Threonine & 9.19 & 9.09 & 9.01 & 9.16 & 0.29 & 0.947 & 9.01 & 9.21 & 0.21 & 0.187 & 0.245 \\
\hline Serine & 9.76 & 9.69 & 9.72 & 9.70 & 0.32 & 0.511 & 9.65 & 9.79 & 0.19 & 0.387 & 0.612 \\
\hline Glutamic acid & 39.5 & 39.3 & 39.4 & 39.1 & 0.51 & 0.115 & 38.9 & 39.7 & 0.38 & 0.199 & 0.318 \\
\hline Glycine & 9.25 & 9.22 & 9.12 & 9.17 & 0.37 & 0.106 & 9.27 & 9.11 & 0.22 & 0.173 & 0.711 \\
\hline Alanine & 13.0 & 12.9 & 12.8 & 12.9 & 0.33 & 0.259 & 12.8 & 12.9 & 0.20 & 0.119 & 0.612 \\
\hline Cysteine & 1.45 & 1.49 & 1.45 & 1.44 & 0.06 & 0.345 & 1.45 & 1.47 & 0.03 & 0.099 & 0.361 \\
\hline Valine & 10.7 & 10.7 & 10.6 & 10.7 & 0.41 & 0.188 & 10.7 & 10.7 & 0.26 & 0.111 & 0.688 \\
\hline Methionine & 5.11 & 5.19 & 5.13 & 5.08 & 0.39 & 0.455 & 5.11 & 5.16 & 0.21 & 0.286 & 0.567 \\
\hline Isoleucine & 11.4 & 11.3 & 11.3 & 11.4 & 0.43 & 0.167 & 11.3 & 11.3 & 0.30 & 0.118 & 0.436 \\
\hline Leucine & 20.8 & 20.7 & 20.5 & 20.7 & 0.46 & 0.742 & 20.6 & 20.7 & 0.31 & 0.247 & 0.537 \\
\hline Tyrosine & 3.26 & 3.24 & 3.22 & 3.29 & 0.12 & 0.202 & 3.27 & 3.24 & 0.08 & 0.311 & 0.478 \\
\hline Phenylalanine & 9.44 & 9.44 & 9.23 & 9.35 & 0.38 & 0.085 & 9.4 & 9.33 & 0.20 & 0.368 & 0.593 \\
\hline Lysine & 18.1 & 18.0 & 17.8 & 18.0 & 0.48 & 0.922 & 17.9 & 18.0 & 0.22 & 0.284 & 0.714 \\
\hline Histidine & 9.15 & 9.21 & 9.19 & 9.16 & 0.28 & 0.107 & 9.19 & 9.16 & 0.16 & 0.093 & 0.278 \\
\hline Arginine & 16.1 & 16.0 & 16.1 & 16.1 & 0.34 & 0.522 & 16.1 & 16.0 & 0.19 & 0.109 & 0.361 \\
\hline $\mathrm{EAA}^{1}$ & 84.6 & 84.5 & 83.7 & 84.3 & 0.59 & 0.436 & 84.1 & 84.4 & 0.21 & 0.519 & 0.891 \\
\hline FRAA $^{2}$ & 102.0 & 102.1 & 101.6 & 101.2 & 1.22 & 0.885 & 101.0 & 101.9 & 0.45 & 0.275 & 0.409 \\
\hline Total & 208.8 & 208.2 & 206.6 & 207.1 & 1.01 & 0.718 & 207.2 & 208.5 & 0.44 & 0.201 & 0.613 \\
\hline
\end{tabular}

\footnotetext{
${ }^{1} \mathrm{EAA}=$ Essential amino acids including valine, methionine, isoleucine, leucine, phenylalanine, lysine and threonine.

${ }^{2}$ FRAA = Flavor-related amino acids including glutamic acid, aspartic acid, glycine, alanine, cysteine, arginine and proline.

${ }^{3}$ Interaction of line and sex.

${ }^{a, b}$ Mean within a row and effect (line or sex) with no common superscripts are significantly different $(\mathrm{p}<0.05)$.
} 


\section{REFERENCES}

Adebambo, A., M. Adeleke, M. Whetto, S. Peters, C. Ikeobi, M. Ozoje, O. Oduguwa, and O. A. Adebambo. 2010. Combining abilities of carcass traits among pure and crossbred meat type chickens. Int. J. Poult. Sci. 9:777-783.

Adebambo, A. O. 2011. Combining abilities among four breeds of chicken for feed efficiency variation: a preliminary assessment for chicken improvement in Nigeria. Trop. Anim. Health Prod. 43:1465-1466.

Chen, G., H. Li, X. Wu, B. Li, K. Xie, G. Dai, K. Chen, X. Zhang, and K. Wang. 2002a. Factors affecting the inosine monophosphate content of muscles in Taihe silkies chickens. Asian-Aust. J. Anim. 15:1359-1363.

Chen, J. L., J. Wen, G. P. Zhao, M. Q. Zheng, and N. Yang. 2005. Genetic parameter estimation for inosine-5-monophosphate and intramuscular fat contents and other meat quality traits in chicken muscle. Hereditas 27:898-902 (In Chinese).

Chen, K., H. Li, and X. Zhang. 2002b. Study on the relation beweent muscle fiber and meat quality in broiler. J. Anim. Veter. Sci. 38:6-7. (In Chinese).

Chen, K. W. 2010. Prospects for the development of quality chicken industry. China Polut. 32:1-4. (In Chinese).

Chen, X., Q. Ma, M. Tang, and C. Ji. 2007. Development of breast muscle and meat quality in Arbor Acres broilers, Jingxing 100 crossbred chickens and Beijing fatty chickens. Meat. Sci. 77:220-227.

Davidek, J. and A. Khan. 1967. Estimation of inosinic acid in chicken muscle and its formation and degradation during post-mortem aging. J. Food. Sci. 32:155-157.

Fanatico, A. C, P. B. Pillai, J. L. Emmert, and C. M. Owens. 2007a. Meat quality of slow-and fast-growing chicken genotypes fed low-nutrient or standard diets and raised indoors or with outdoor access. Poult. Sci. 86:2245-2255.

Fanatico, A. C, P. B. Pillai, J. L. Emmert, and E. E. Gbur. 2007b. Sensory attributes of slow-and fast-growing chicken genotypes raised indoors or with outdoor access. Poult. Sci. 86:24412449.

Gwartney, B., S. J. Jones, and C. R. Calkins. 1992. Response time of broiler chickens to cimaterol: meat tenderness, muscle composition fiber size, and carcass characteristics. J. Anim. Sci. 70:2144-2150.

Hawk, P. B. 1947. Kjeldahl method. Pract. Physiol. Chem. 12:814822

Holownia, K., M. Chinnan, A. Reynolds, and P. Koehler. 2003. Evaluation of induced color changes in chicken breast meat during simulation of pink color defect. Poult. Sci. 82:10491059 .

Jaturasitha, S., T. Srikanchai, M. Kreuzer, and M. Wicke. 2008. Differences in carcass and meat characteristics between chicken indigenous to northern Thailand (Black-boned and Thai native) and imported extensive breeds (Bresse and Rhode Island Red). Poult. Sci. 87:160-169.

Jin, X. S., J. W. Liu, G. X. Liu, and C. J. G. 2005. The Research on Crossing-breed Effect of Native chicken. J. Jilin. Agric. Sci. 30:45-46. (In Chinese).

Lan, X., Q. Zhu, Y. P. Liu, H. D. Yin, Y. Zhang, J. Li, and X. L. Zhao. 2010. Breeding effect of laying performance of erlang mountainous chickens of the first generation. China. Poult.
23:8-11. (In Chinese).

Le Bihan-Duval, E., N. Millet, and H. Remignon. 1999. Broiler meat quality: effect of selection for increased carcass quality and estimates of genetic parameters. Poult. Sci. 78:822-826.

Li, D. L., J. L. Chen, J. Wen, G. P. zhang, M. Q. Zheng, and J. Li. 2007. Crossing performance among different poputation of Beijing fatty chicken. China. Polut. 29:23-25. (In Chinese).

Luque de Castro, M. D., and F. Priego-Capote. 2010. Soxhlet extraction: Past and present panacea. J. Chromatogr. A. 1217:2383-2389.

Odeh, F., G. Cadd, and D. Satterlee. 2003. Genetic characterization of stress responsiveness in Japanese quail. 1. Analyses of line effects and combining abilities by diallel crosses. Poult. Sci. 82:25-30.

Owens, C., E. Hirschler, R. Martinez-Dawson, and A. Sams. 2000. The characterization and incidence of pale, soft, exudative turkey meat in a commercial plant. Poult. Sci. 79:553-558.

Qi, F. H., C. S. Xu, Z. S. Zhao, and Z. X. Zhang. 2006. Comparative study on carcass of different economic types chickens. China Anim. Husb. Vet. Med. 33:24-26. (In Chinese)

Remignon, H., V. Desrosiers, and G. Marche. 1996. Influence of increasing breast meat yield on muscle histology and meat quality in the chicken. Repord. Nutr. Dev. 36:523-530.

Shaarani, S. M., K. P. Nott, and L. D. Hall. 2006. Combination of NMR and MRI quantitation of moisture and structure changes for convection cooking of fresh chicken meat. Meat. Sci. 72:398-403.

Song, H. L., J. Zhang, and H. H. Zhao. 2002. Concentrations of IMP in variance chicken lines. Food Sci. 2:103-105. (In Chinese).

Stell, R. and J. Torrie. 1980. Principles and procedures of statistics: a biometrical approach. 2 ed.

Tang, H., Y. Gong, C. Wu, J. Jiang, Y. Wang, and K. Li. 2009. Variation of meat quality traits among five genotypes of chicken. Poult. Sci. 88:2212-2218.

Van Laack, R., S. Stevens, and K. Stalder. 2001. The influence of ultimate $\mathrm{pH}$ and intramuscular fat content on pork tenderness and tenderization. J. Anim. Sci. 79:392-397.

Wang, G., J. X. Zheng, Z. C. Hou, L. J. Qu, N. Yang, and G. Y. Xu. 2009a. Comparison study on meat quality of AA broilers and Beijing fatty chickens. China Poult. 31:11-18. (In Chinese).

Wang, H. C., J. Xue, W. Ma, and J. Wang. 2008. Crossing experiment on improving productive performances of Dagu chicken. Anim. Husb. Vet. Med. 40:44-45. (In Chinese).

Wang, K., S. Shi, T. Dou, and H. Sun. 2009b. Effect of a freerange raising system on growth performance, carcass yield, and meat quality of slow-growing chicken. Poult. Sci. 88:2219-2223.

Wattanachant, S., S. Benjakul, and D. Ledward. 2004. Composition, color, and texture of Thai indigenous and broiler chicken muscles. Poult. Sci. 83:123-128.

Woelfel, R., C. Owens, E. Hirschler, R. Martinez-Dawson, and A. Sams. 2002. The characterization and incidence of pale, soft, and exudative broiler meat in a commercial processing plant. Poult. Sci. 81:579-584.

Xiao, L. H. 2007. Advances in chicnken meat quality Jiangxi. J. Anim. Husb. Vet. 2:5-7. (In Chinese).

Xie, K. Z., G. J. Dai, J. Y. Wang, and Y. P. Gu. 2008. Study on the meat production performance and meat quality of Jinghai 
yellow chickens. J. Yangzhou. Univ. (Agric. Life. Sci. Ed) 29:45-48. (In Chinese).

Yin, H., Z. Zhang, X. Lan, X. Zhao, Y. Wang, and Q. Zhu. 2011. Association of MyF5, MyF6 and MyOG gene polymorphisms with carcass traits in Chinese Meat Type Quality chicken populations. J. Anim. Vet. Adv. 10:704-708.

Zhang, Z., Y. Liu, X. Jiang, H. Du, and Q. Zhu. 2008. Study on association of single nucleotide polymorphism of CAPN1 gene with muscle fibre and carcass traits in quality chicken populations. J. Anim. Breed. Genet. 125:258-264.
Zhao, G., H. Cui, R. Liu, M. Zheng, J. Chen, and J. Wen. 2011. Comparison of breast muscle meat quality in 2 broiler breeds. Poult. Sci. 90:2355-2359.

Zhao, X., P. Siegel, Y. Liu, Y. Wang, E. Gilbert, Q. Zhu, and L. Zhang. 2012. Housing system affects broiler characteristics of local Chinese breed reciprocal crosses. Poult. Sci. 91:24052410.

Zhu, J. R. 2004. Experimental guidance of poultry science. Shanghai Scientific and Technical Pulishers, Shanghai. (In Chinese). 